\title{
CIHR announces winners of health research awards
}

— Cite as: CMAJ 2017 May 15;189:E705. doi: 10.1503/cmaj.1095426

$\mathbf{T}$ he Canadian Institutes of Health Research (CIHR) announced the four winners of its inaugural Gold Leaf Prizes for excellence in health research.

The winners are John Dick of the Molecular Genetics Department of the University of Toronto; Gregory Steinberg of the Division of Endocrinology and Metabolism at McMaster University; Charlotte Loppie of the School of Public Health and Social Policy at the University of Victoria; and the final winner is the British Columbia Centre for Excellence in HIV/ AIDS.

"By providing the evidence to inform government policy, your research is contributing to improved health and wellbeing for all Canadians," federal Health Minister Dr. Jane Philpott said in a media release.

Dick received the award for discovery for being the first scientist to identify cancer stem cells, work that may lead to improved cancer treatments. Steinberg received the award for outstanding earlycareer achievements for his research on obesity, diabetes, nutrition and exercise. Loppie won for patient engagement for her efforts to involve Indigenous peoples in research projects. The British Columbia Centre for Excellence in HIV/AIDS was awarded a prize for impact for its 25-year body of work in HIV/AIDS.

The Gold Leaf Prizes were created by $\mathrm{CIHR}$ to recognize excellence in the "all pillars of research": biomedical; clinical; health services and policy; and population and public health. They will be awarded every two years and each has a value of $\$ 100000$. The winners were selected based on recommendations from an expert panel.

Roger Collier, CMAJ

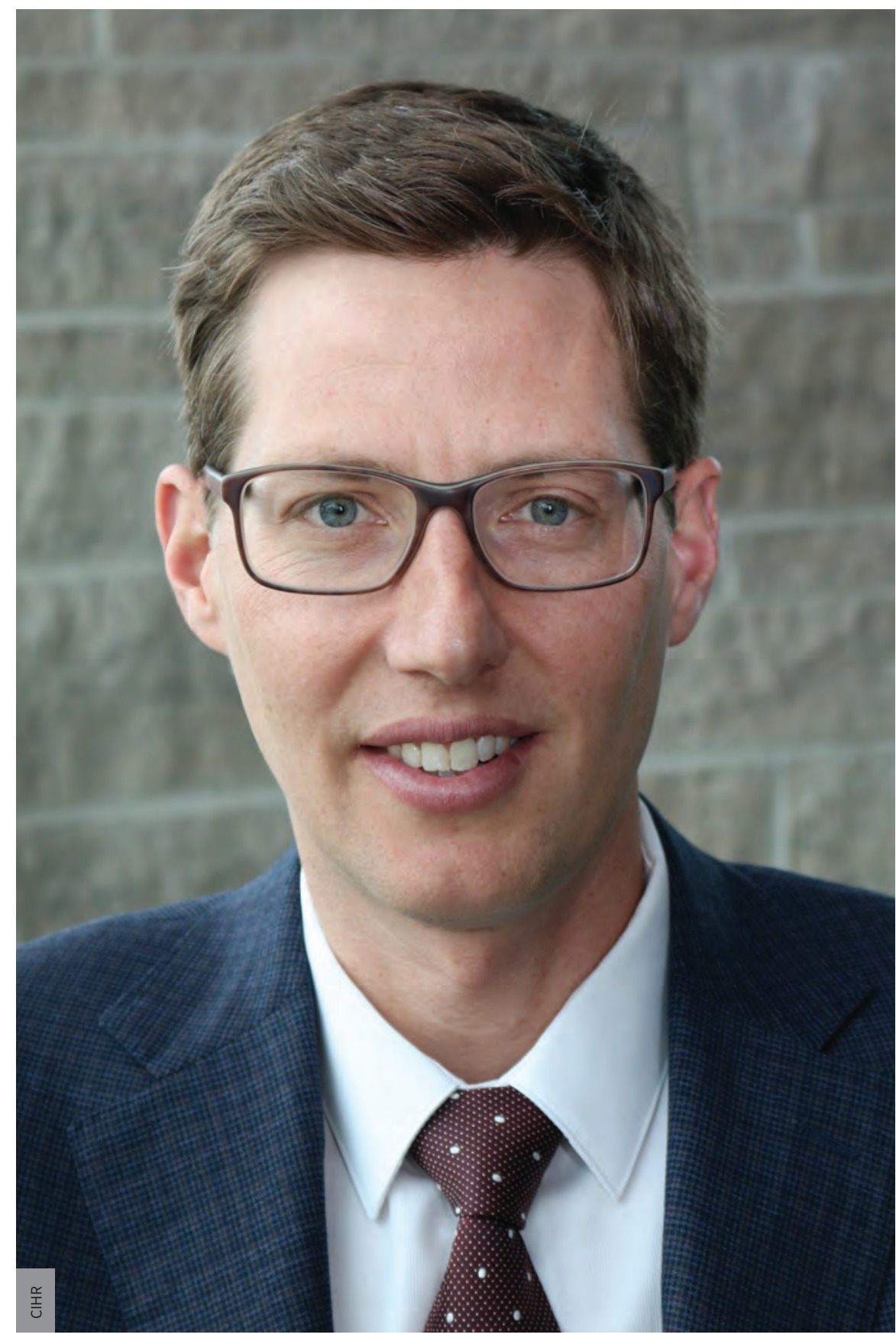

Gregory Steinberg was recognized by CIHR for outstanding early-career achievement. 